\title{
The impact of using thromboprophylactic medication by pregnant women on the hemodynamics of fetus and uterus
}

\author{
Emre Zafer \\ Department of Gynecology and Obstetrics, Faculty of Medicine, Aydin Adnan Menderes University, Aydin, Turkey
}

\begin{abstract}
Objective: To define potential effects of anticoagulants at prophylactic doses due to various reasons during pregnancy on the blood flow of fetus and uterus.

Methods: In this prospective monocenter study, blood flow parameters of umbilical artery (UmA), middle cerebral artery (MCA) and uterine artery (UtA) of pregnant women, who were at second and third trimesters and were using anticoagulants (low-molecularweight heparin-LMWH and/or acetylsalicylic acid-ASA), were evaluated by Doppler ultrasonography. The pregnant women who were at similar ages and weeks of gestation and not using anticoagulants were selected as the control group. Two groups were compared by "independent samples t-test" and "Mann-Whitney U test" in terms of clinical, demographic and Doppler findings. In the sub-group analysis, only the cases using $\mathrm{LMWH}$ and $\mathrm{LMWH}+\mathrm{ASA}$ were compared to the control group.

Results: A total of 63 cases were included in the study. No statistically significant difference was found in the comparison of demographic and clinical data of $36(57.1 \%)$ pregnant women using anticoagulant and $27(42.9 \%)$ pregnant women not using any anticoagulant except the presence of poor obstetric history $(\mathrm{p}<0.001)$. There was no difference between two groups in terms of Doppler data on the arteries studied $(\mathrm{p}>0.005)$. However, when the groups were compared in terms of their trimester period, it was found that 3rd trimester MCA PSV values of anticoagulant group was significantly different than of the control group $(\mathrm{p}=0.037)$. It was found in the anticoagulant subgroup analysis that the concomitant use of $\mathrm{LMWH}$ and ASA caused a significant change in MCA PSV values ( $\mathrm{p}=0.006)$.

Conclusion: We found that the use of LMWH or ASA during pregnancy did not cause any significant change which can be seen by Doppler in the hemodynamics of umbilical artery, fetal middle cerebral artery and uterine artery. However, we considered that the concomitant use of both anticoagulants has a more distinguishable effect on MCA value during 3rd trimester of pregnancy.
\end{abstract}

Keywords: Anticoagulant, pregnancy, Doppler, umbilical artery, uterine artery, middle cerebral artery.
Özet: Gebelerde tromboprofilaktik ilaç kullanımının fetüs ve uterus kan akış dinamiklerine etkisi

Amaç: Gebelikleri süresince çeşitli nedenlerle profilaktik dozda antikoagülasyon başlanan olguların fetal ve uterin kan dolaşımlarındaki olası etkileri tanımlamak.

Yöntem: Prospektif yapılan bu tek merkezli çalışmada antikoagülan (düşük molekül ağırlıklı heparin-DMAH ve/veya asetilsalisilik asit-ASA) kullanan, ikinci ve üçüncü trimesterdeki gebelerde; umbilikal arter (UmA), orta serebral arter (MCA) ve uterin arter (UtA) kan akış parametreleri Doppler ultrasonografi ile değerlendirildi. Antikoagülan kullanmayan ve benzer yaş ve gestasyonel haftadaki gebeler ise kontrol grubu olarak seçildi. İki grup klinik, demografik ve Doppler bulguları açısından "bağımsız grup t testi" ve "Mann-Whitney U testi" ile karşılaştırıldı. Alt grup analizinde, sadece DMAH ve DMAH ile beraber ASA kullananlar kontrol grubu ile karşılaştırıldılar.

Bulgular: Çalışmaya toplam 63 olgu dahil edildi. Antikoagülan kullanan 36 (\% 57.1) gebe ile herhangi bir antikoagülan kullanmayan 27 (\% 42.9) gebenin kötü obstetrik özgeçmiş varlığı dışındaki $(\mathrm{p}<0.001)$ demografik ve klinik verilerinin karşılaştırılmasında istatistiksel açıdan anlamlı bir fark bulunmadı. Çalışılan damarlardaki Doppler verileri açısından da iki grup arasında fark izlenmedi ( $>0.005)$. Ancak trimester ayırımı yapıldığında antikoagülan grubunun 3. trimester MCA PSV değerlerinin kontrol grubundan anlamlı derecede farklı olduğu izlendi $(\mathrm{p}=0.037)$. Antikoagülan alt grup analizinde ise DMAH ve ASA'nın birlikte kullanımının MCA PSV değerlerinde anlamlı değişime neden olduğu bulundu $(\mathrm{p}=0.006)$.

Sonuç: Gebelikte DMAH veya ASA kullanımının umbilikal, fetal orta serebral arter ve uterin arter akış dinamiklerinde Doppler ile izlenebilir anlamlı bir değişikliğe yol açmadığı izlendi. Ancak her iki antikoagülanın birden kullanımının, gebeliğin 3. trimesterinde MCA üzerinde daha fark edilebilir bir etki gösterebileceği düşünüldü.

Anahtar sözcükler: Antikoagülan, gebelik, Doppler, umbilikal arter, uterin arter, orta serebral arter.
Correspondence: Emre Zafer, MD. Department of Gynecology and Obstetrics, Faculty of Medicine, Aydın Adnan Menderes University, Aydın, Turkey. e-mail: dr.emrezafer@gmail.com Received: November 14, 2018; Accepted: December 182018

Please cite this article as: Zafer $\mathrm{E}$. The impact of using thromboprophylactic medication by pregnant women on the hemodynamics of fetus and uterus. Perinatal Journal 2018;26(3):148-154.

(C2018 Perinatal Medicine Foundation
Available online at: www.perinataljournal.com/20180263010 doi: $10.2399 /$ prn.18.0263010 QR (Quick Response) Code:

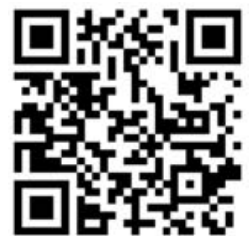




\section{Introduction}

Thromboprophylaxis during pregnancy usually aims one of two major goals: Maternal thromboembolism prophylaxis and preventing poor obstetric outcomes. The potential roles of coagulative changes in maternalfetal combination and congenital thrombophilia on recurrent first trimester miscarriages, second-third trimester fetal deaths, ablatio placentae and even intrauterine growth retardation have been investigated frequently. ${ }^{[1]}$ By the recommendations published by different professional societies and organizations on this popular topic, it has been aimed to prevent anticoagulant use during pregnancy through incorrect and/or missing indications. ${ }^{[2,3]}$

The usage areas of Doppler ultrasonography have been expanding day by day thanks to its superiority in analyzing hemodynamics. Changes in fetal-placental and uterine hemodynamics can be identified without requiring an invasive procedure on many positions of circulation system, particularly umbilical artery, fetal middle cerebral artery and uterine artery, for topics such as intrauterine growth retardation, fetal anemia followup and management, preeclampsia and even the prediction of poor obstetric outcomes. ${ }^{[4,5]}$

Uterine artery provides blood flow to uterine and therefore to placenta during pregnancy. In recent years, uterine artery Doppler (UtAD) ultrasonography has been used particularly for the prediction of the development of severe preeclampsia. ${ }^{[6]}$ Significant parameters reflecting placental resistance in particular are obtained with the analysis of umbilical artery by Doppler ultrasonography (UmAD). Thanks to these parameters, fetal-neonatal mortality in the management of intrauterine growth retardation can be decreased significantly. ${ }^{[4]}$ Hemodynamics of fetal middle cerebral artery (MCA) are very important for the antenatal follow-up and management of clinical problems such as feto-maternal hemorrhages and Rh incompatibility in terms of the brain sparing effect defined as centralization and therefore the intrauterine follow-up of fetal anemia. ${ }^{[7]}$ It is also very important to predict the poor obstetric outcomes as a component of "cerebro-placental ratio" (CPR) which has been investigated frequently in the recent years. ${ }^{[5]}$

Although the parameters measured by Doppler ultrasonography technique, which is commonly used in obstetrics and reassures clinical evaluation, vary accord- ing to the user due to technical reasons such as angle of insonation and broadness of samples, their standardization is quite simple. However, apart from the techniques of ultrasonography use, these parameters can be affected by the clinical characteristics of patients. Therefore, it is worth investigating how anticoagulants affect fetal and placental hemodynamics during the pregnancy. While there is particularly a considerable amount of pregnant women who use anticoagulant due to the subjective criterion of "poor obstetric history", ${ }^{[8]}$ potential effects of anticoagulants on Doppler parameters can be crucial.

Therefore, we aimed to compare uterine, umbilical and fetal middle cerebral artery Doppler parameters between the pregnant women who started to use anticoagulant due to the subjective criterion of poor obstetric history and the pregnant women who did not use anticoagulant and to investigate the effects of anticoagulant at prophylactic dose on the outcomes in this study.

\section{Methods}

\section{Study population}

The study group consisted of the cases who admitted to the maternity clinic of Application and Research Hospital, Medicine Faculty, Aydın Adnan Menderes University and for whom thromboprophylaxis was initiated by another center during the first trimester of their pregnancies. The inclusion criterion was "continuing to use low-molecular-weight heparin (LMWH) at prophylactic dose and/or low-dose acetylsalicylic acid (ASA) at second or third trimester since the first trimester". The exclusion criteria were determined as pregnancies below 18-year-old, multiple pregnancies, known fetal genetic or other anomalies, using anticoagulant due to indications (i.e. deep vein thrombosis or prosthetic heart valve, anticardiolipin antibody positivity, presence of lupus anticoagulant) except poor obstetric history, using anticoagulant irregularly, and starting to use anticoagulant before pregnancy or after first trimester.

The approval of Ethics Committee of NonInvasive Clinical Researches, Medicine Faculty, Aydın Adnan Menderes University (protocol no. 2015/38) was obtained before the study. During routine obstetric ultrasonography, umbilical, uterine and middle cerebral artery Doppler ultrasonography evaluations 
were done in all patients and the values were recorded together with other demographic and clinical data. As clinical and demographic data, age, gravida, parity, week of gestation, smoking habit, blood pressure, anticoagulant use and type, medication use for chronic reasons other than anticoagulants, presence of poor obstetric history and obstetric and non-obstetric problems in the current pregnancy were investigated. Two or more first trimester pregnancy loss in previous pregnancies, second or third trimester fetal death, ablatio placentae, and hypertensive diseases during gestation were considered "poor obstetric history". The conditions in pregnancy during study such as pregestational or gestational diabetes, hypertensive diseases of gestation, chronic hypertension, ablatio placentae, and epilepsy were classified as "presence of current clinical problems". Presence of congenital thrombophilia (i.e. factor V Leiden mutation) was not taken into consideration.

\section{Doppler ultrasonography}

Doppler measurements were carried out by an ultrasonography device with $7 \mathrm{MHz}$ convex probe (C3-7IM, Accuvix V20, Samsung- Medison, Gyeonggi, South Korea). For UtAD measurements, it was paid attention to keep insonation angle below 30 degrees at every measurement. Pulsatility index (PI), resistance index (RI), and systole/diastole ratio (S/D) were recorded bilaterally. The mean of right and left measurements was taken during the analysis. In UmAD samplings, the sampling was done on the area close to the placental end, and PI, RI and $\mathrm{S} / \mathrm{D}$ values were recorded. Insonation angle was kept below 10 degrees in MCA measurements, and peak systolic velocity (MCA PSV) and PI values were recorded.

\section{Statistics}

When the statistical power analysis was performed for the study by taking the study of Bar et al. as reference, it was calculated that at least 20 cases should be studied in each group to conduct the research as effect size would be 0.3 , alpha would be 0.05 and statistical power would be $80 \%$ for UmA PI variable. ${ }^{[9]}$ KolmogorovSmirnov test was used for the normal distribution analysis of numerical variables. The comparison between the groups for numerical variables exhibiting normal distribution was done by "independent samples t-test" and the data were presented as mean \pm standard deviation. Mann-Whitney $U$ test was used to compare numerical variables without normal distribution, and descriptive statistical data were presented as median (25th-75th percentile). Chi-square test was used for the analysis of categorical data. The cases where "pvalue" is below 0.05 were considered statistically significant.

\section{Results}

A total of 56 cases using anticoagulant and 27 cases not using anticoagulant were analyzed for the study. Of the cases using anticoagulant, 2 were excluded from the study due to DVT history, 5 due to multiple pregnancy, 4 due to anticoagulant use after first trimester and 9 due to irregular use of anticoagulant. The data of remaining $36(57.1 \%)$ cases using anticoagulant were analyzed as study group. Similarly, the data of 27 $(42.9 \%)$ pregnant women not using any type of anticoagulant were recorded as the control group. The study population consisted of a total of 63 pregnant women.

Except the parameter of "presence of poor obstetric history" ( $\mathrm{p}<0.001)$, no statistically significant difference was found in the comparison of demographic and clinical data of the study group using anticoagulant and the control group not using any anticoagulant $(p>0.05$, Table 1). No significant difference was found when the groups were compared in terms of Doppler parameters analyzed (UmA PI, UmA SD, UtA PI, MCA PI and MCA PSV) ( $>0.05$, Table 2).

When the cases were compared only in terms of third trimester Doppler data, it was found that MCA PSV values of the study group were lower than the control group ( $\mathrm{p}=0.037$, Table 3$)$.

When the cases were analyzed by grouping according to the anticoagulant type they used, LMWH, ASA and LMWH+ASA sub-groups were identified. However, the cases using only ASA were not included in the analysis as their number was low $(n=4)$. It was observed that MCA PSV values of the cases using $\mathrm{LMWH}+\mathrm{ASA}$ were lower than those of the control group ( $\mathrm{p}=0.006)$. There was no significant difference in other sub-groups and other parameters (Table 4).

When sub-analysis was performed according to the anticoagulant type and trimester simultaneously, the only sub-group reaching sufficient number for statistical analysis was the sub-group consisting of cases at their third trimester and using only LMWH $(n=15)$. 
Table 1. Comparison of the demographic and clinical data of the groups.

\begin{tabular}{|c|c|c|c|}
\hline & $\begin{array}{l}\text { Anticoagulant group } \\
\qquad(\mathrm{n}=36)\end{array}$ & $\begin{array}{l}\text { Control group } \\
(n=27)\end{array}$ & p-value \\
\hline Age (year)* & $31.05 \pm 6.06$ & $30.14 \pm 5.97$ & 0.556 \\
\hline Week of gestation ${ }^{\dagger}$ & $30(26-34)$ & $32(28-34)$ & 0.611 \\
\hline Second trimester & $12(33.3)$ & $6(22.2)$ & \\
\hline Third trimester ${ }^{\ddagger}$ & $24(66.6)$ & $21(77.8)$ & \\
\hline Parity $^{+}$ & $1(0-1)$ & $1(0-2)$ & 0.953 \\
\hline Systolic blood pressure $(\mathrm{mmHg})^{\dagger}$ & $110(104.2-118.7)$ & $110(100-130)$ & 0.713 \\
\hline Diastolic blood pressure $(\mathrm{mmHg})^{+}$ & $70(61.25-70.0)$ & $70(65-80)$ & 0.360 \\
\hline Cases with poor obstetric history ${ }^{\ddagger}$ & $26(72.2)$ & $6(22.2)$ & $<0.001$ \\
\hline Cases with obstetric and other medical problems in this pregnancy ${ }^{\ddagger}$ & $11(30.6)$ & $17(63.0)$ & 0.021 \\
\hline Smoker cases ${ }^{\ddagger}$ & $6(14.8)$ & $4(16.7)$ & 1.000 \\
\hline Cases using non-anticoagulant medication due to chronic disease ${ }^{\ddagger}$ & $4(11.1)$ & $10(37.0)$ & 0.032 \\
\hline Anticoagulant type ${ }^{\ddagger}$ & $36(100)$ & - & \\
\hline LMWH only & $20(55.5)$ & & \\
\hline LMWH+ASA & $11(30.5)$ & & \\
\hline ASA only & $5(14)$ & & \\
\hline
\end{tabular}

${ }^{*}$ Mean \pm standard deviation; ${ }^{+}$median (25th-75th percentile); ${ }^{\prime n}$ (\%). ASA: acetylsalicylic acid; LMWH: Low-molecular-weight heparin.

There was no significant difference between this subgroup and the control group in terms of Doppler data ( $>0.05$, no data was presented).

\section{Discussion}

In this study, we aimed to analyze potential changes in Doppler dynamics of uterine, fetal middle cerebral and umbilical arteries in pregnant women who started to use anticoagulant due to the subjective criterion of "poor obstetric history". We observed that the concomitant use of low-molecular-weight heparin (LMWH) and acetylsalicylic acid (ASA) may be associated with the low MCA PSV values.

Anticoagulants are commonly used in many poor obstetric problems such as intrauterine fetal death, ablatio placentae, early-severe preeclampsia and intrauterine growth retardation but early pregnancy losses in particular. Moreover, it is also known that anticoagulant is prescribed in pregnancies achieved by assisted reproductive technologies. However, it has not been shown that such common use of anticoagulants improved the outcomes. ${ }^{[10,11]}$ Although various professional obstetrics societies published bulletins providing evidence-based recommendations on anticoagulant indications, its off-label use is quite common. ${ }^{[8]}$ In addition, when anticoagulant is prescribed upon the subjective criterion of "poor obstetric history", it is very difficult to convince patients to discontinue this medication.
Table 2. Comparison of Doppler parameters between two groups.

\begin{tabular}{lccc} 
& $\begin{array}{c}\text { Anticoagulant group } \\
(\mathbf{n}=\mathbf{3 6})\end{array}$ & $\begin{array}{c}\text { Control group } \\
(\mathbf{n}=\mathbf{2 7})\end{array}$ & $\mathbf{p}$-value \\
$\mathrm{MCA} \mathrm{PSV}^{*}$ & $38.59 \pm 9.02$ & $43.17 \pm 10.5$ & 0.071 \\
$\mathrm{MCA} \mathrm{PI}^{+}$ & $1.85(1.58-2.06)$ & $2.11(1.55-2.43)$ & 0.209 \\
$\mathrm{UmA} \mathrm{PI}^{+}$ & $1.09(0.96-1.47)$ & $1.25(1.00-1.36)$ & 0.484 \\
$\mathrm{UmA} \mathrm{SD}^{\dagger}$ & $3.06(2.69-4.20)$ & $3.38(2.67-4.00)$ & 0.526 \\
$\mathrm{UtA} \mathrm{PI}^{*}$ & $1.27 \pm 0.50$ & $1.21 \pm 0.39$ & 0.576 \\
\hline
\end{tabular}

*Mean \pm standard deviation; ${ }^{+}$median (25th-75th percentile). MCA PSV: medium cerebral artery peak systolic velocity; PI: pulsatility index; SD: systole/diastole; ratio; UmA: umbilical artery Doppler; UtA: uterin artery Doppler.

In the obstetrics practice, the area of use of Doppler ultrasonography has become quite popular and it has proved its positive contribution on perinatal outcomes in many clinical scenarios. Although different results

Table 3. Comparison of third trimester Doppler data between the anticoagulant group and the control group.

\begin{tabular}{lccc} 
& $\begin{array}{c}\text { Control group } \\
(\mathbf{n}=\mathbf{2 0})\end{array}$ & $\begin{array}{c}\text { Anticoagulant group } \\
(\mathbf{n}=\mathbf{2 4})\end{array}$ & p-value \\
MCA PSV $^{*}$ & $47.37 \pm 7.49$ & $42.3 \pm 6.61$ & $\mathrm{p}=0.037$ \\
$\mathrm{MCA} \mathrm{PI}^{+}$ & $2.1(1.5-2.46)$ & $1.9(1.65-2.3)$ & $\mathrm{p}=0.524$ \\
$\mathrm{UmA} \mathrm{PI}^{+}$ & $1.2(1.0-1.4)$ & $1.0(0.9-1.4)$ & $\mathrm{p}=0.364$ \\
$\mathrm{UmA} \mathrm{SD}^{+}$ & $3.1(2.4-3.9)$ & $2.9(2.5-3.3)$ & $\mathrm{p}=0.364$ \\
UtA PI $^{+}$ & $1.2(0.9-1.4)$ & $1.3(1.0-1.5)$ & $\mathrm{p}=0.448$ \\
\hline
\end{tabular}

One third trimester control case was not included due to missing data. *Mean \pm standard deviation; ${ }^{\dagger}$ median (25th-75th percentile). MCA PSV: medium cerebral artery peak systolic velocity; PI: pulsatility index; SD: systole/diastole; ratio; UmA: umbilical artery Doppler; UtA: uterin artery Doppler. 
Table 4. Distribution of Doppler data according to anticoagulant type.

\begin{tabular}{|c|c|c|c|}
\hline & $\begin{array}{c}\text { Control group } \\
(n=36)\end{array}$ & $\begin{array}{l}\text { LMWH only } \\
\qquad(\mathrm{n}=27)\end{array}$ & $\begin{array}{l}\text { LMWH+ASA } \\
(\mathrm{n}=11)\end{array}$ \\
\hline MCA PSV* & $43.1 \pm 10.5$ & $42.3 \pm 8.1(p=0.751)$ & $32.7 \pm 8.5(p=0.006)$ \\
\hline MCA Pl+ & $2.1(1.5-2.4)$ & $1.9(1.6-2.3)(p=0.748)$ & $1.8(1.6-1.9)(p=0.219)$ \\
\hline UmA PI+ & $1.2(1.0-1.4)$ & $1.0(0.9-1.5)(p=0.335)$ & $1.1(1.0-1.5)(p=0.973)$ \\
\hline UmA SD ${ }^{+}$ & $3.9(2.7-4.0)$ & $2.9(2.6-4.0)(p=0.394)$ & $3.1(2.9-4.7)(p=0.666)$ \\
\hline UtA PI ${ }^{+}$ & $1.2(1.0-1.4)$ & $1.0(0.9-1.4)(p=0.235)$ & $1.4(1.1-1.6)(p=0.149)$ \\
\hline
\end{tabular}

*Mean \pm standard deviation; ${ }^{\dagger}$ median (25th-75th percentile). ASA: Low-dose acetylsalicylic acid; LMWH: Low-molecular-weight heparin; MCA PSV: medium cerebral artery peak systolic velocity; PI: pulsatility index; SD: systole/diastole; ratio; UmA: umbilical artery Doppler; UtA: uterin artery Doppler.

can be obtained due to "user factor" as in all ultrasonographic evaluations, it is possible to standardize it by measurement criteria and user trainings. ${ }^{[12]}$ However, apart from the user factor, the impact of demographic and clinical variables on Doppler parameters is a topic which is investigated less. In a cross-sectional study published very recently, it has been shown that demographic and clinical characteristics may significantly affect Doppler parameters ${ }^{[13]}$ Although there are some studies investigating the impacts of medications, which affect artery physiology or intravascular volume during pregnancy, on Doppler data, ${ }^{[1,15]}$ there are fewer studies on the potential relationship between anticoagulant use during pregnancy and Doppler parameters.

For example, a study conducted on 178 pregnancies of 51 cases with hereditary thrombophilia using LMWH reported that fewer abnormal Doppler results (UmA and MCA) were observed in the cases using anticoagulant compared to those not using anticoagulant. This study claimed that LMWH might have an impact on Doppler values in the group with hereditary thrombophilia. However, the population of this study also includes thromboembolism unlike our study. ${ }^{[16]}$

Bar et al. compared the pregnant women who started to use LMWH due to poor obstetric history to the pregnant women who started to use LMWH+ASA due to hereditary thrombophilia concurrent with poor obstetric history. ${ }^{[17]}$ They reported a significant decrease in UtA PI values of the group using $\mathrm{LMWH}+\mathrm{ASA}$. Although this prospective study did not provide any data on MCA, it indicates that the use of LMWH+ASA during pregnancy may cause changes measurable by Doppler. However, in a similar study, Çok et al. reported different observations by LMWH only. This retrospective research reported that there was no significant difference in midtrimester UtAD values of 64 pregnant women with thrombophilia using LMWH compared to the control group. ${ }^{[18]}$ Similarly, we did not observe any significant change in UtAD parameters of pregnant women by anticoagulant at prophylactic doses in our study.

In a recent study conducted on 139 pregnant women with hereditary thrombophilia, the authors reported that there was no difference between the cases using LMWH and the cases using LMWH+ASA in terms of uterine and umbilical artery Doppler parameters. ${ }^{[19]}$ Therefore, it can be considered that uterine and umbilical artery Doppler values are not different among the pregnant women using LMWH and/or the pregnant women using LMWH+ASA. We also found in our study that the anticoagulant use due to subjective criteria did not cause a significant change in $\mathrm{UtAD}$ and $\mathrm{UmAD}$ values.

The number of studies concluding that ASA use during pregnancy has no significant impact on Doppler parameters is high. For example, a prospective research reported that there was no significant difference between placebo and ASA in terms of UmAD values. ${ }^{[9]}$ Similarly, it was reported that $\mathrm{UmAD}$ and UtAD values of pregnant women who had anticardiolipin antibody positivity and used ASA were not different than normal pregnant women. ${ }^{[20]}$

MCA Doppler ultrasonography, which has important areas of use in pregnancy, is important for the management of fetal and fetoplacental problems which are especially defined as brain sparing effect and concomitantly developed with the transformation of cerebral high resistant flow into low resistant. In their randomized study, Grab et al. concluded that the use of ASA did not cause a significant difference in MCA and other (UmA, UtA) Doppler values. ${ }^{[21]}$ In their study, the authors selected pregnant women with the history of intrauterine growth retardation or chronic hypertension 
as the study group. In our study, the number of pregnant women using ASA only was very low so it was not possible to derive a statistically significant result; however, we observed a significant decrease in MCA PSV median values of the cases using LMWH+ASA than those not using medication. On the other hand, Younis et al. reported in their study that MCA Doppler values were normal in the pregnant women who had thrombophilia and used $\mathrm{LMWH}+\mathrm{ASA}^{[22]}$ However, their results should be interpreted carefully as they did not have a control group.

When the studies published in English in PubMed database are reviewed, it can be seen that a couple of studies published in this database on this topic were conducted usually on pregnant women with the history of thrombophilia and thromboembolism or with the problems such as intrauterine growth retardation during study period. We could not find any study investigating the potential impact of off-label anticoagulant use on the Doppler parameters during pregnancy. Therefore, the heterogeneity of pregnant women population among other studies and our study makes it difficult for making a clear deduction. One of the limitations of our study is the sampling size. Even though we reached sufficient number of cases by performing statistical power analysis before the study, this number may not be enough to provide a reliable result when a secondary analysis is performed by grouping according to anticoagulant sub-types. Thus, this factor should be taken into consideration when interpreting our results.

\section{Conclusion}

Apart from the current indications, we did not find a significant difference in umbilical artery, uterine artery and fetal cerebral artery Doppler parameters of pregnant women using LMWH due to the subjective criterion of "poor obstetric outcome" compared to the control group. However, the concomitant use of LMWH and ASA may cause changes measurable by Doppler ultrasonography in the hemodynamics of fetal middle cerebral artery.

Conflicts of Interest: No conflicts declared.

\section{References}

1. Scheres LJJ, Bistervels IM, Middeldorp S. Everything the clinician needs to know about evidence-based anticoagulation in pregnancy. Blood Rev 2018;33:82-97.

2. ACOG Practice Bulletin No. 196 Summary: thromboembolism in pregnancy. Obstet Gynecol 2018;132:243-8.
3. ACOG Practice Bulletin No. 197: Inherited thrombophilias in pregnancy. Obstet Gynecol 2018;132:e18-e34.

4. Alfirevic Z, Stampalija T, Dowswell T. Fetal and umbilical Doppler ultrasound in high-risk pregnancies. Cochrane Database Syst Rev 2017;6:CD007529.

5. Vollgraff Heidweiller-Schreurs CA, De Boer MA, Heymans MW, Schoonmade LJ, Bossuyt PMM, Mol BWJ, et al. Prognostic accuracy of cerebroplacental ratio and middle cerebral artery Doppler for adverse perinatal outcome: systematic review and meta-analysis. Ultrasound Obstet Gynecol 2018; $51: 313-22$.

6. Velauthar L, Plana MN, Kalidindi M, Zamora J, Thilaganathan B, Illanes SE, et al. First-trimester uterine artery Doppler and adverse pregnancy outcome: a meta-analysis involving 55,974 women. Ultrasound Obstet Gynecol 2014;43: 500-7.

7. Mari G, Norton ME, Stone J, Berghella V, Sciscione AC, Tate D, et al.; Society for Maternal-Fetal Medicine. Society for Maternal-Fetal Medicine (SMFM) Clinical Guideline \#8: the fetus at risk for anemia - diagnosis and management. Society for Maternal-Fetal Medicine. Am J Obstet Gynecol 2015;212:697-710.

8. Shen YM, Tsai J, Taiwo E, Gavva C, Yates SG, Patel V, et al. Analysis of thrombophilia test ordering practices at an academic center: a proposal for appropriate testing to reduce harm and cost. PLoS One 2016;11:e0155326.

9. Bar J, Hod M, Pardo J, Fisch B, Rabinerson D, Kaplan B, et al. Effect on fetal circulation of low-dose aspirin for prevention and treatment of pre-eclampsia and intrauterine growth restriction: Doppler flow study. Ultrasound Obstet Gynecol 1997;9:262-5.

10. Alfirevic Z, Roberts D, Martlew V. How strong is the association between maternal thrombophilia and adverse pregnancy outcome? A systematic review. Eur J Obstet Gynecol Reprod Biol 2002;101:6-14.

11. Clark P, Walker ID, Langhorne P, Crichton L, Thomson A, Greaves M, et al.; Scottish Pregnancy Intervention Study (SPIN) collaborators. SPIN (Scottish Pregnancy Intervention) study: a multicenter, randomized controlled trial of low-molecular-weight heparin and low-dose aspirin in women with recurrent miscarriage. Blood 2010;115:4162-7.

12. Deane C. Doppler ultrasound: principles and practice. In: Nicolaides K, Rizzo G, Hecher K, Ximenes R, editors. Doppler in obstetrics. Diploma in Fetal Medicine and ISUOG Educational Series. London: Fetal Medicine Foundation; 2002. p. 4-24. Available from: https://fetalmedicine.org/var/ uploads/Doppler-in-Obstetrics.pdf

13. Ciobanu A, Wright A, Syngelaki A, Wright D, Akolekar R, Nicolaides KH. Fetal Medicine Foundation reference ranges for umbilical artery and middle cerebral artery pulsatility index and cerebroplacental ratio. Ultrasound Obstet Gynecol 2018 Oct 24. doi: 10.1002/uog.20157

14. Pedersen BW, Ringholm L, Damm P,Tabor A, Søgaard K, Hellmuth E, et al. Stable fetal hemodynamics measured by Doppler flow after initiation of anti-hypertensive treatment with methyldopa in pregnant women with diabetes. J Matern Fetal Neonatal Med 2016;29:550-3. 
15. Carr DB, Gavrila D, Brateng D, Easterling TR. Maternal hemodynamic changes associated with furosemide treatment. Hypertens Pregnancy 2007;26:173-8.

16. Magriples U, Ozcan T, Karne A, Copel JA. The effect of anticoagulation on antenatal ultrasound findings in pregnant women with thrombophilia. J Matern Fetal Neonatal Med 2006; 19:27-30.

17. Bar J, Mashiah R, Cohen-Sacher B, Hod M, Orvieto R, BenRafael Z, et al. Effect of thrombophylaxis on uterine and fetal circulation in pregnant women with a history of pregnancy complications. Thromb Res 2001;101:235-41.

18. Cok T, Tarim E, Iskender C. Comparison of uterine artery Doppler in pregnant women with thrombophilia treated by LMWHs and without thrombophilia. Arch Gynecol Obstet 2012;286:575-9.

19. Abheiden C, Van Hoorn ME, Hague WM, Kostense PJ, van Pampus MG, de Vries J. Does low-molecular-weight heparin influence fetal growth or uterine and umbilical arterial Doppler in women with a history of early-onset uteroplacental insufficiency and an inheritable thrombophilia? Secondary randomised controlled trial results. BJOG 2016;123:797-805.

20. Blumenfeld Z, Weiner Z, Lorber M, Sujov P, Thaler I. Anticardiolipin antibodies in patients with recurrent pregnancy wastage: treatment and uterine blood flow. Obstet Gynecol 1991;78:584-9.

21. Grab D, Paulus WE, Erdmann M, Terinde R, Oberhoffer R, Lang D, et al. Effects of low-dose aspirin on uterine and fetal blood flow during pregnancy: results of a randomized, placebo-controlled, double-blind trial. Ultrasound Obstet Gynecol 2000;15:19-27.

22. Younis JS, Ohel G, Brenner B, Haddad S, Lanir N, Ben-Ami $M$. The effect of thrombophylaxis on pregnancy outcome in patients with recurrent pregnancy loss associated with factor V Leiden mutation. BJOG 2000;107:415-9. 